\title{
Trees Configuration Model for Hot Humid Tropic Urban Parks
}

\author{
Jono Wardoyo1, Eko Budihardjo², Eddy Prianto ${ }^{3}$, Muh Nur ${ }^{4}$ \\ 1 Department of Architecture , Brawijaya University \\ 2 Department of Architecture, Diponegoro University \\ 3 Department of Architecture, Diponegoro University \\ ${ }^{4}$ Department of Architecture, Diponegoro University \\ Email address of corresponding author : mas_joon@yahoo.com
}

\begin{abstract}
Main climatic thermal problems in urban park in hot humid tropic area are how to minimize high solar radiation and to optimize the wind. Trees have potentials in ameliorating urban park microclimate. Trees configuration is one of determining factors to get benefit of vegetation potential in hot humid urban park.

Microclimate simulation of 3 (three) different tree configurations in selected urban park model is carried out with three-dimensional numerical model, ENVI-Met V.3.1 which simulates the microclimatic changes within urban environments in a high spatial and temporal resolution. The simulation results show that an east - west orientation tree line configuration model has a higher temperature reduction compared with the base case model.
\end{abstract}

Keywords: Urban park, hot humid tropic, tree configuration model

\section{Introduction}

Urban open spaces in hot humid tropic city need to protect from high intensity of solar radiation that bring higher environmental air temperature. It also need more wind velocity to create more comfort condition for pedestrian. Vegetation has potential to reduce environmental temperature. Its form and configuration influence solar radiation, temperature, air humidity and wind of an urban microclimate.

Cooling effect by vegetation had already observed by some previous researchers. Zahoor (1997) in Pakistan which had hot dry climate, found that vegetation has significant influenced to local temperature and effective in reducing air temperature about $6-7^{\circ} \mathrm{F}$. Saxena (2001) by computer simulation also found that temperature on housing neighborhood surrounded by tree has $1,34^{\circ} \mathrm{F}$ lower than which is not.

Hiraoka (2002) and Tauhid, et al, (2007) studied the air temperature distribution around the tree. By computer simulation, Hiraoka (2002) observed the air temperature distribution around $10 \mathrm{~m}$ height single tree. He found that air temperature at 20 meters from tree center has a $0.02 \mathrm{degC}$ hotter than the tree centre. A field measurement of the air temperature distribution around Ficus benjamina by Tauhid, et al, (2007) in hot humid tropical city of Semarang found the similar result with Hiraoka. Both of them fou nd that the further distance from a tree canopy centre the cooling effect of a tree was less than the closer one. The distance and direction of this cooling effect were depends on the wind velocity and direction. Structural characteristics of the tree also have effect on the wind velocity and direction. 
Trees also have influence to the pattern of air movement through guidance, filtration, obstruction and deflection. Affectivity of air movement controlling depends on vegetation characteristic. Geometry, height, permeability and crown of the vegetation are the structural vegetal characteristic that influenced to air movement around tree. (Scudo, 2002) Instead of its obstruction effect, current structural characteristics of trees could have a channelling effect. (Boutet, 1989) This channeling effect is very important in attempt to optimize the wind velocity in urban space.

Potential benefit of the tree in modifying microclimate should be optimized in order to create more comfortable condition in hot humid tropic urban park. Beside of its physical characteristics, the configuration of the trees is one of the determining factors to get benefit of vegetation potential in hot humid urban open space (Wardoyo, et al, 2008). This paper will present the result of limited research simulation on the influence of trees configuration on urban park microclimate.

\section{Materials and Method}

\subsection{Computer Simulation Program EnviMet V.3.1Format Paragraf}

Numerous modeling and simulation computer program has been developed in order to conduct research about relation between architecture or urban form and microclimate. Base calculation of those computer programs varies from empirical calculation to numerical/mathematical calculation.

EnviMet V.3.1 is a three-dimensional non hydrostatic model simulation program developed by Dr. Michael Bruse from Research Group of Climatology Institute for Geography, Ruhr-University of Bochum German. It simulates the microclimatic dynamics with in a daily cycle in complex urban structures, i.e. buildings with various shapes and heights as well as vegetation. The major advantage of ENVI-met is that it is one of the first models that seeks to reproduce the major processes in the atmosphere that affect the microclimate, including the simulation of wind flows, turbulence, radiation fluxes, temperature and humidity, on a well-founded physical basis (i.e. the fundamental laws of fluid dynamics and thermodynamics). (Ali-Toudert, 2005) It also requires relatively few input parameters, and calculates all important meteorological factors, e.g. air and surface temperatures, wind speed and direction, air humidity, short-wave and long-wave radiation fluxes, as well as the mean radiant temperature needed for comfort analyses. (Bruse, 2005)

This EnviMet V.3.1 simulation program was used to run a 6 hours microclimate simulation of 4 urban park models. The simulation date was chosen on $23^{\text {rd }}$ June as the sun "critical" position. Potential air temperature, specific humidity and wind velocity are the main climatic element as the result of the simulation.

\subsection{Urban Park and Trees Configuration Model}

Location of this study is Semarang Indonesia $\left(7^{\circ} \mathrm{S}, 110.3^{\circ} \mathrm{E}\right)$ which has hot humid tropic climate characteristic. Topography of the city is between $0-348$ meters asl (above the sea level) makes a unique characteristic of its topography. Based on its topography, the city is divided into three areas: the seaside area (0 - 5 m asl), lowland area (5-100 $\mathrm{m}$ asl) and highland area (above $100 \mathrm{~m}$ asl). Housing, industrial and tourism areas are dominant land uses in seaside area. Large parts of lowland area are used for economic and housing areas. While high land area plays as supporting area for both lowland area and seaside area. 
Climate characteristic of Semarang is hot humid tropic climate. There is two seasons with in this climate characteristic: wet season and dry season. Based on Semarang Meteorological Station data from 1996 - 2000, the average monthly air temperature at 07.00 am is range from $24.30^{\circ} \mathrm{C}$ to $26.10^{\circ} \mathrm{C}$, the average monthly air temperature at 01.00 pm is range from $29.34^{\circ} \mathrm{C}$ to $33.16^{\circ} \mathrm{C}$ and the average monthly air temperature at $06.00 \mathrm{pm}$ is range from $27.20^{\circ} \mathrm{C}$ to $29.20^{\circ} \mathrm{C}$.(Figure 1a). The average monthly relative humidity is range from $68.2 \%$ to $84.6 \%$. (Figure $1 \mathrm{~b}$ )
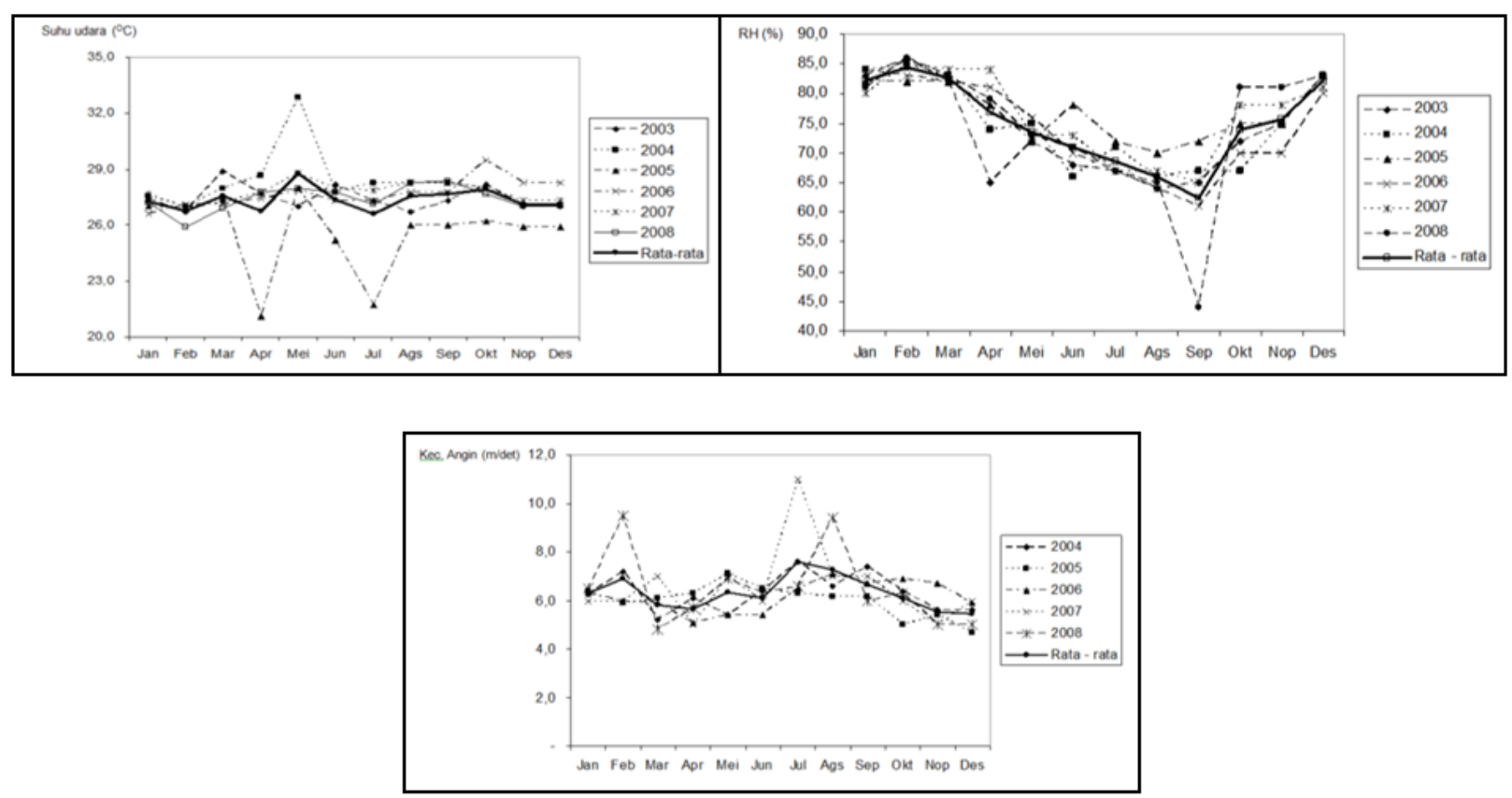

Figure 1. Annual Climate Data of Semarang

(Source: Meteorological Station, 2008)

There are 144 urban green open spaces with more than 13.4 ha total area in Semarang. It consists of small pocket parks, roadside parks and urban parks. Among these parks, 33 parks are active urban parks while the rest are passive urban parks. Total area of the active parks is only 41.1 ha or about $30.5 \%$ of total area of urban park in Semarang. It means that Semarang still need more active urban parks. Basic form typology of urban park in Semarang can be divided into 3 (three) basic forms. There are square form like Lapangan Pancasila, triangle form like Taman KB and circle form like Taman Tugumuda.

Various trees and vegetations can be found in urban parks in Semarang. The ground covers of these parks are almost the same. There are Axonopus compressus or Zoysia matrella. While for the low and tall shrubs, there are Accasia auricullisformis, Acalipha $s p$, Bougenville sp, Canna sp etc.

Urban park model that used in this simulation research is square form with $10 \times 10$ square meters area. This urban park model surrounding by 4 meters width of street and about 3 stories ( 20 meters height) commercial building located around the urban park model. The park model is covered by $18 \mathrm{~cm}$ height grass. While trees character used in this simulation is about 10 meters height with distinct crown layer. The tree model represents Accasia auriculisformis which is easily found in urban park in Semarang. 
Model 0 as base model has only ground cover vegetation and no trees. Model 1 has tree line on the edge of the urban park model. Trees configuration on model 2 is North South orientation rows tree. West - East orientation rows tree are the configuration on model 3. (Figure 2)
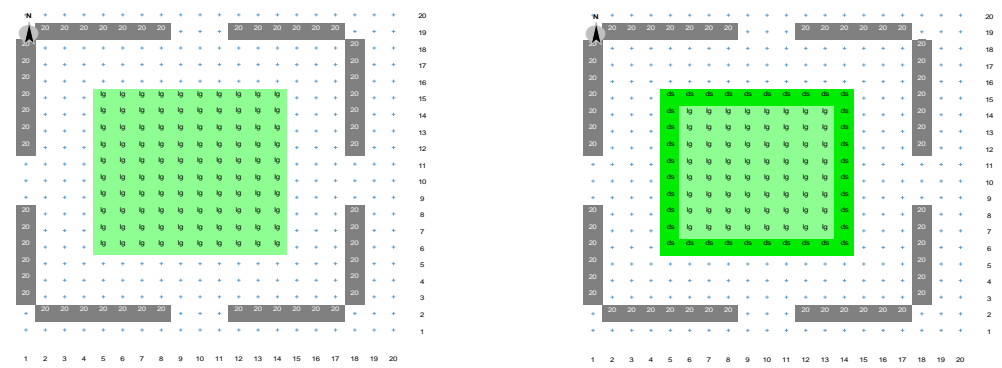

Model 0 (Base model)
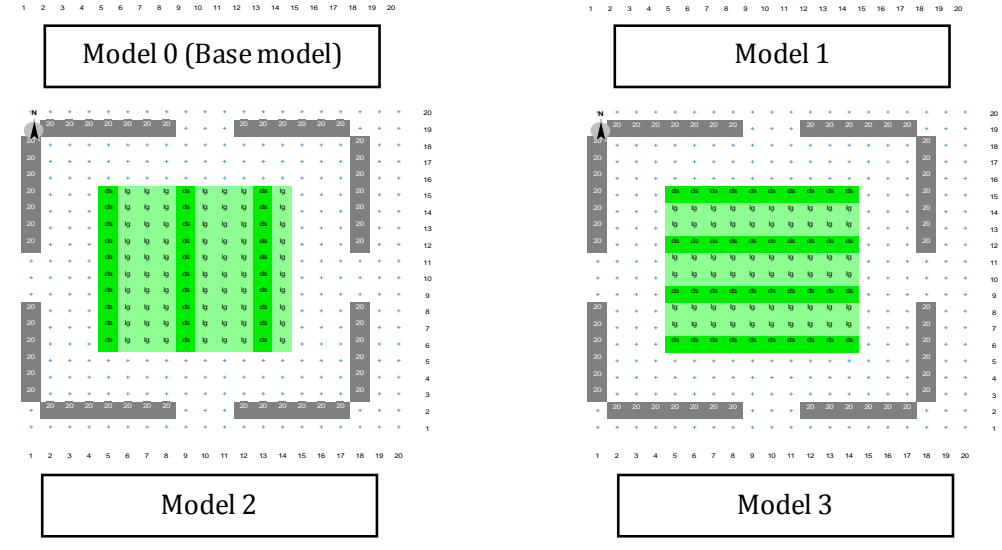

Figure 2. Trees configurations Models (sumber, tahun)

\subsection{Simulation}

Basic configuration data used for the simulation refer to the yearly average of Semarang climate data. Geographical position of the urban park model also use the geographic location of Semarang. The simulation runs at $23^{\text {rd }}$ June when the sun position has reached its critical position. Simulation began at $09.00 \mathrm{am}$ and finished at $15.00 \mathrm{pm}$. Complete basic configuration for the simulation can be shown at the graphic below. (Fig.3) 


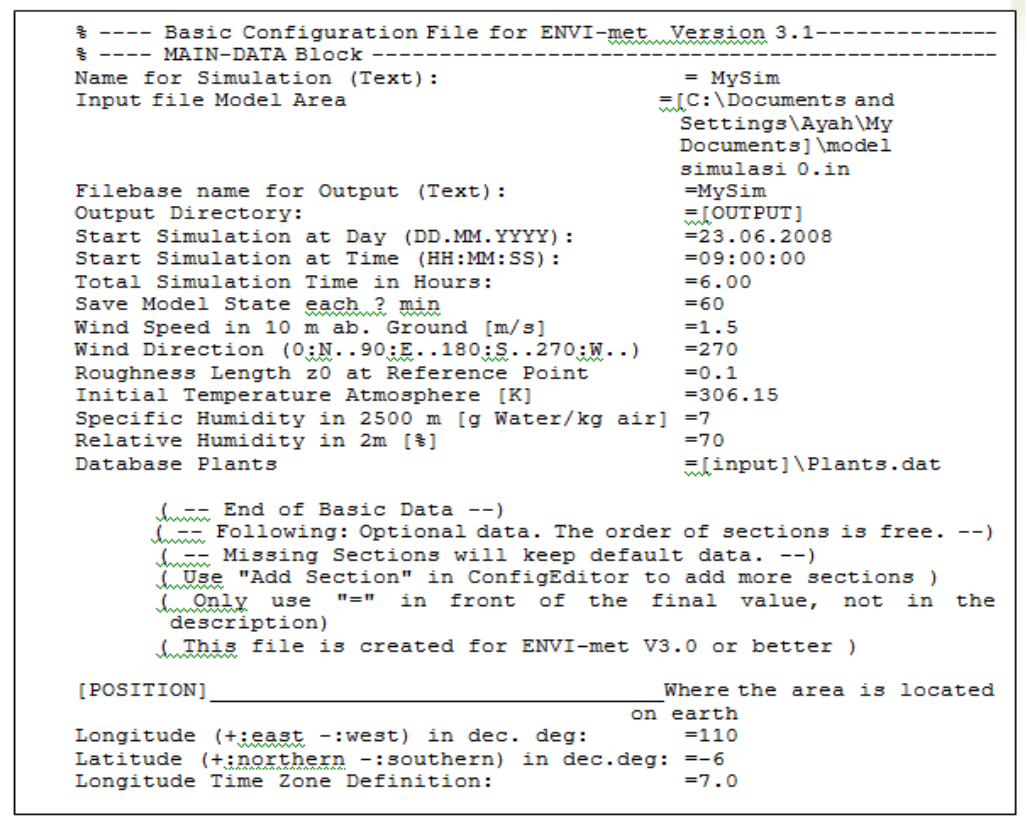

Fig. 3. Basic Configuration Data Simulation

\section{Results and Discussion}

\subsection{Potential Temperature}

ENVI-Met simulation result of Potential Temperature has shown on figure 4 below. All urban park models have a similar pattern of the potential temperature simulation result. They almost have a same potential temperature result on 09.00-10.00 am until 11.00-12.00 at noon. At the 12.00-13.00 until 13.00-14.00 pm, the potential temperature of all models have reached their maximum values. Still the potential temperature of the base model is greater than the other model. It range from $30.6-32.3^{0}$ C.(see fig. 4 )

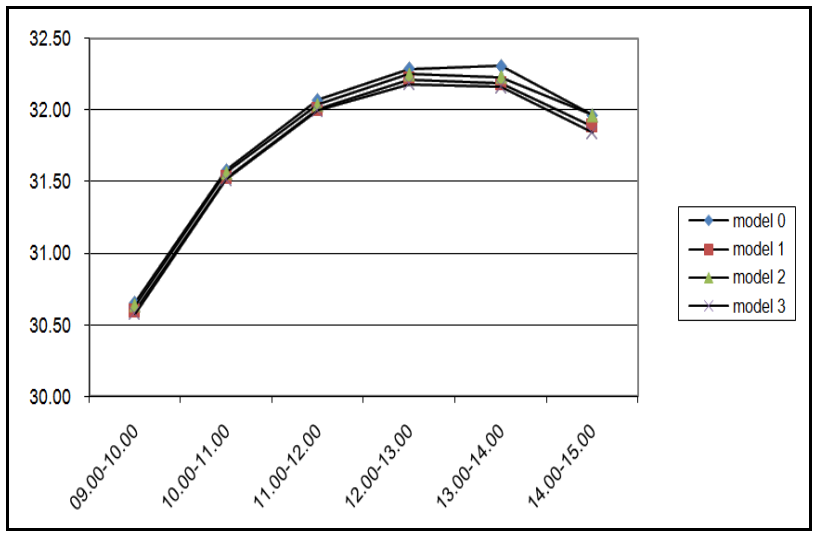

Fig. 4. Potential Temperatur Simulation Result 


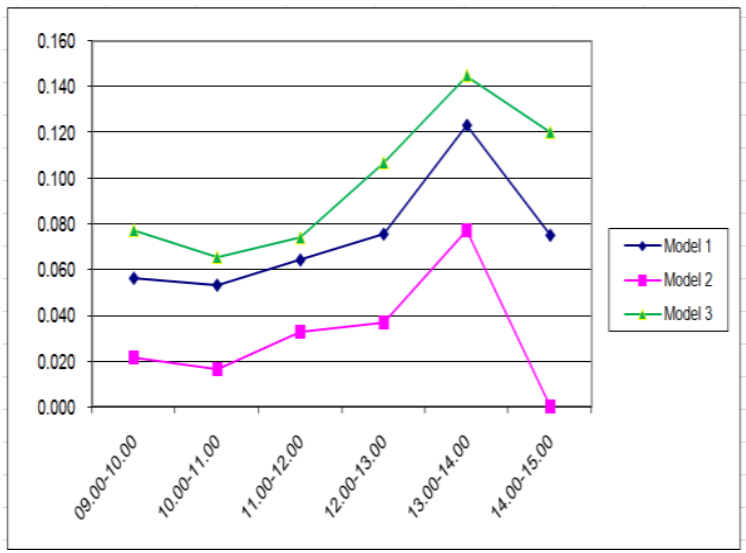

Fig. 5. Potential Temperature Differences between Base Model and Model

Potential Temperature difference between Model 3 and Base Model is the highest among the other models. It is shown in figure 5, that the Potential Temperature difference between Model 3 and Base Model has reach its maximum value at 13.00-14.00 pm simulation time. The range of the potential temperature difference between base model and model 3 is about $0.05-0.14$ only.

\subsection{Wind Velocity}

ENVI-Met Wind velocity simulation result of Model 1, Model 2 and Model 3 is less than the Base Model (fig. 6). It is considered that there is no tree in Base Model. Thus the wind has found no obstacles in this base urban park model.

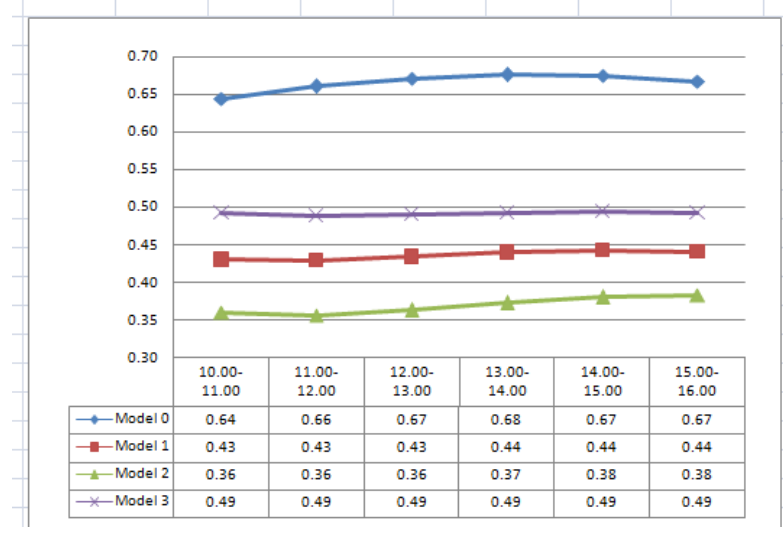

Fig.6 Wind Velocity Simulation Result

Trees configuration on model 2 was like more obstruction rather than guidance for the wind flow. While trees configuration on model 1 was block the wind flow. But the wind velocity of model 1 is higher than model 2 because tree configuration on model 1 only placed on the edge of the urban park model.

\subsection{Specific Humidity}


Air humidity is one of the climate element that determining comfortable feeling. Specific Humidity simulation result of model 2 is the lowest than other models. While model 1 and model 3 almost have the same value (fig. 7)

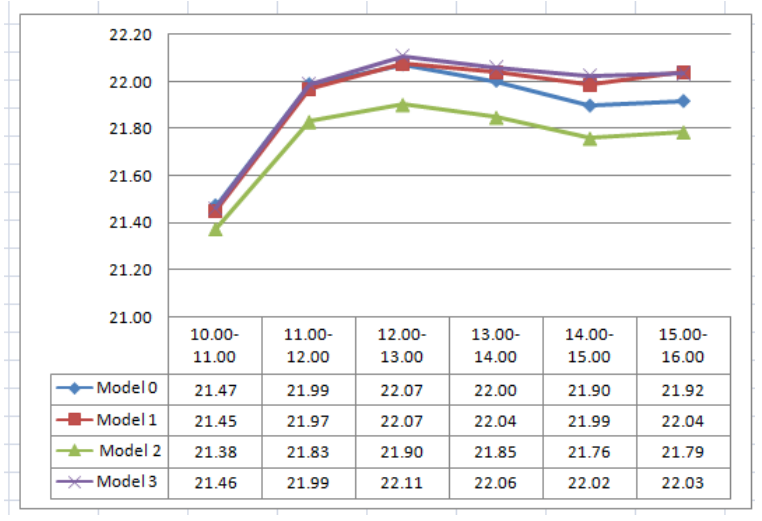

Fig. 3. Basic Configuration Data Simulation

EnviMet V.3.1 simulation result confirmed with Scudo (2002) that different vegetation configuration on urban open space has different microclimate condition. Altough the maximum different value of potential temperature between the base model and model 3 is only about $0.14^{\circ} \mathrm{C}$. The area of urban park model that is not wide enough caused the small value of Potential Temperature difference among the models.

The East-West tree lines orientation in Model 3 has made "channeling effect" of the wind. Since the wind direction on simulation basic configuration was 270 degree from the North, this "channeling effect" on model 3 was not optimum yet

\section{Conclusion}

Vegetations have potentials in ameliorating urban open space microclimate. Vegetations configuration is one of determining factors to get benefit of vegetation potential in hot humid urban open space.

North-South orientation tree lines configuration has best simulation result in reducing air temperature and increasing wind velocity in hot humid urban park. Further research is needed to study the optimization of this tree model configuration in ameliorating urban space microclimate.

\section{Acknowledgement}

The authors would like to thank the Higher Education Indonesian National Education Department for supporting this study through the scholarship for Mr Wardoyo. Thanks also to blind referrer for their valuable comment on this article.

\section{References}


Ali-Toudert, Fazia. 2005. Dependence of Outdoor Thermal Comfort on Street Design in Hot and Dry Climate. Dissertation unpublished. Berichte des Meteorologischen Institutes der Universität Freiburg.

Bruse, Michael. 2008. ENVI-met homepage: www.envi-met.com.

Hiraoka, Hishashi. 2002. Simulating the Microclimate Produced by a Single Tree, Ecole d'Architecture de Nantes (CERMA), Proceedings International Workshop on Architectural an Urban Ambient Environment, Nantes, 6 -8 February (2002)

Scudo, Gianni. 2002. Thermal Comfort in Greenspaces. Milan: Proceeding COST C 11 "Green structures and urban planning".

Tauhid, 2008. Kajian Jarak Jangkau Efek Vegetasi Pohon terhadap Suhu Udara pada Siang Hari di Perkotaan(Studi Kasus: Kawasan Simpang Lima Kota Semarang). Thesis Unpublished. Semarang: Program Studi Ilmu Lingkungan Program Pascasarjana Universitas Diponegoro.

Wardoyo, Jono; Budihardjo, Eko; Priyanto, Eddy; and Nur, Muh. 2008. Vegetation Configuration as Microclimate Control Strategy In Hot Humid Tropic Urban Open Space. INTERNATIONAL SEMINAR IN SUSTAINABLE ENVIRONMENT \& ARCHITECTURE 2008, Kuala Lumpur, Malaysia, 1-3 December 2008. 